\title{
Modeling of radial variations of wood properties in naturally regenerated trees of Betula platyphylla grown in Selenge, Mongolia
}

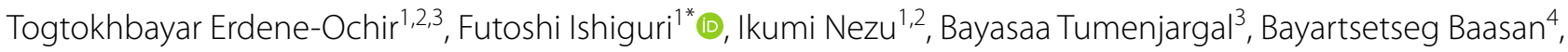
Ganbaatar Chultem4, Jyunichi Ohshima and Shinso Yokota ${ }^{1}$

\begin{abstract}
Wood properties, such as annual ring width, wood fiber length, vessel element length, basic density, air-dry density, dynamic Young's modulus, modulus of elasticity (MOE), modulus of rupture (MOR), absorbed energy in impact bending, compressive strength parallel to grain, and shearing strength, were investigated for wood from 10 naturally regenerated trees of Betula platyphylla Sukaczev in Mandal, Selenge, Mongolia. Mixed-effects models were used to evaluate the radial variations in the wood properties. The mean values of wood properties obtained in the present study were in almost the same range, with a few exceptions, as those reported by other researchers for other Betula species. The radial variations of wood properties in B. platyphylla were well-fitted to a nonlinear mixed-effects model (logarithmic formula); all examined wood properties increased from the pith and then became constant toward the bark side. The wood properties significantly differed between the core and outer wood. Basic density, air-dry density, and dynamic Young's modulus were significantly correlated with MOE, MOR, and compressive strength. It is concluded that when the wood of B. platyphylla is utilized as raw materials for solid wood products, the differences between the core wood and outer wood should be considered. In addition, the selection of wood with higher strength properties can be achieved using the wood density and dynamic Young's modulus as indicators.
\end{abstract}

Keywords: Betula platyphylla, Core wood, Outer wood, Wood properties

\section{Introduction}

The Betula species is distributed in the temperate to subarctic zones of northeast Asia, including western and northern China, Japan, Korea, and Mongolia [1-6]. The basic wood properties of the Betula species have been investigated by several researchers for efficient utilization of the wood from this species (e.g., [1, 7-9]).

Understanding the radial variation of wood properties is important for utilizing wood resources. In

\footnotetext{
${ }^{*}$ Correspondence: ishiguri@cc.utsunomiya-u.ac.jp

1 School of Agriculture, Utsunomiya University, Utsunomiya, Tochigi

321-8505, Japan

Full list of author information is available at the end of the article
}

general, wood properties in hardwoods vary within the tree: unstable wood properties are found in core wood near the pith, while stable properties are found in the outer wood near the bark or cambium [10-14]. The radial variations in cell length are usually used to determine the boundary between these two regions in hardwood species [9, 14, 15]. In Betula platyphylla Sukaczev var. japonica (Miq.) H. Hara naturally grown in Japan, we recently reported that the boundary determined by radial variations of fiber length was around 1.5 to $4.2 \mathrm{~cm}$ from the pith or the 10th to 17 th annual ring from the pith [9]. Similar results in terms of radial variations of the density and mechanical properties have been obtained in other Betula species (e.g., B. 
ermanii Cham., B. maximowicziana Regel, B. pendula Roth, and B. platyphylla), where the region around 5 to $8 \mathrm{~cm}$ from the pith has been clearly marked as a low-density and low-strength properties region [1618]. These radial variations of wood properties might be related to the xylem maturation process $[9,11-15$, 18]. Therefore, further research is needed to clarify the xylem maturation process for $B$. platyphylla trees grown in Mongolia to understand the core wood and outer wood properties.

The relationships between growth characteristics and wood properties have been investigated for both softwoods and hardwoods $[10,11,19]$. Several researchers have investigated these relationships in Betula species specifically (e.g., [2, 3, 8, 9, 20]). Heräjärvi [20] reported significant positive correlations between wood density and static bending properties, such as the modulus of elasticity (MOE) and modulus of rupture (MOR), in 60-90-year-old B. pendula and B. pubescens Ehrh. trees grown on a plantation in Finland. When correlations were investigated between growth rate with cell length, specific gravity, and mechanical properties for $B$. pendula, B. platyphylla, B. pubescens, and B. utilis, growth rate had very little correlation with the wood properties in these Betula species [1, 2]. However, relationships among the growth characteristics and/or wood properties are still unclear for B. platyphylla trees grown in Mongolia.

The objectives of this study are to investigate the wood properties of $B$. platyphylla trees naturally grown in Mandal, Selenge, Mongolia to establish the sustainable forestry and effectively utilize the wood resources. Radial variations of wood properties were evaluated by developing linear or nonlinear mixed-effects models. In addition, the differences in wood properties between core wood and outer wood. Furthermore, the relationships among measured wood properties were also investigated.

\section{Materials and methods \\ Materials}

Figure 1 shows the experimental procedures followed in the present study. Ten Betula platyphylla Sukaczev trees were collected from a natural forest in Mandal, Selenge, Mongolia $\left(36^{\circ} 47^{\prime} \mathrm{N}, 139^{\circ} 29^{\prime} \mathrm{E}\right.$; approximately $1100 \mathrm{~m}$ above the sea level). Although tree age was unknown, because these were naturally regenerated trees, the number of annual rings ranged from 33 to 70 at $1.8 \mathrm{~m}$ above the ground level (Fig. 1). The stem diameter measured at $1.3 \mathrm{~m}$ above the ground by a tape measure (F10020DM, KDS, Kyoto, Japan) ranged from 13.2 to $23.0 \mathrm{~cm}$ $($ mean $=15.4 \mathrm{~cm})($ Fig. 1). After harvesting the trees, two disks $(1 \mathrm{~cm}$ in thickness) and logs (ca. $50 \mathrm{~cm}$ in length)

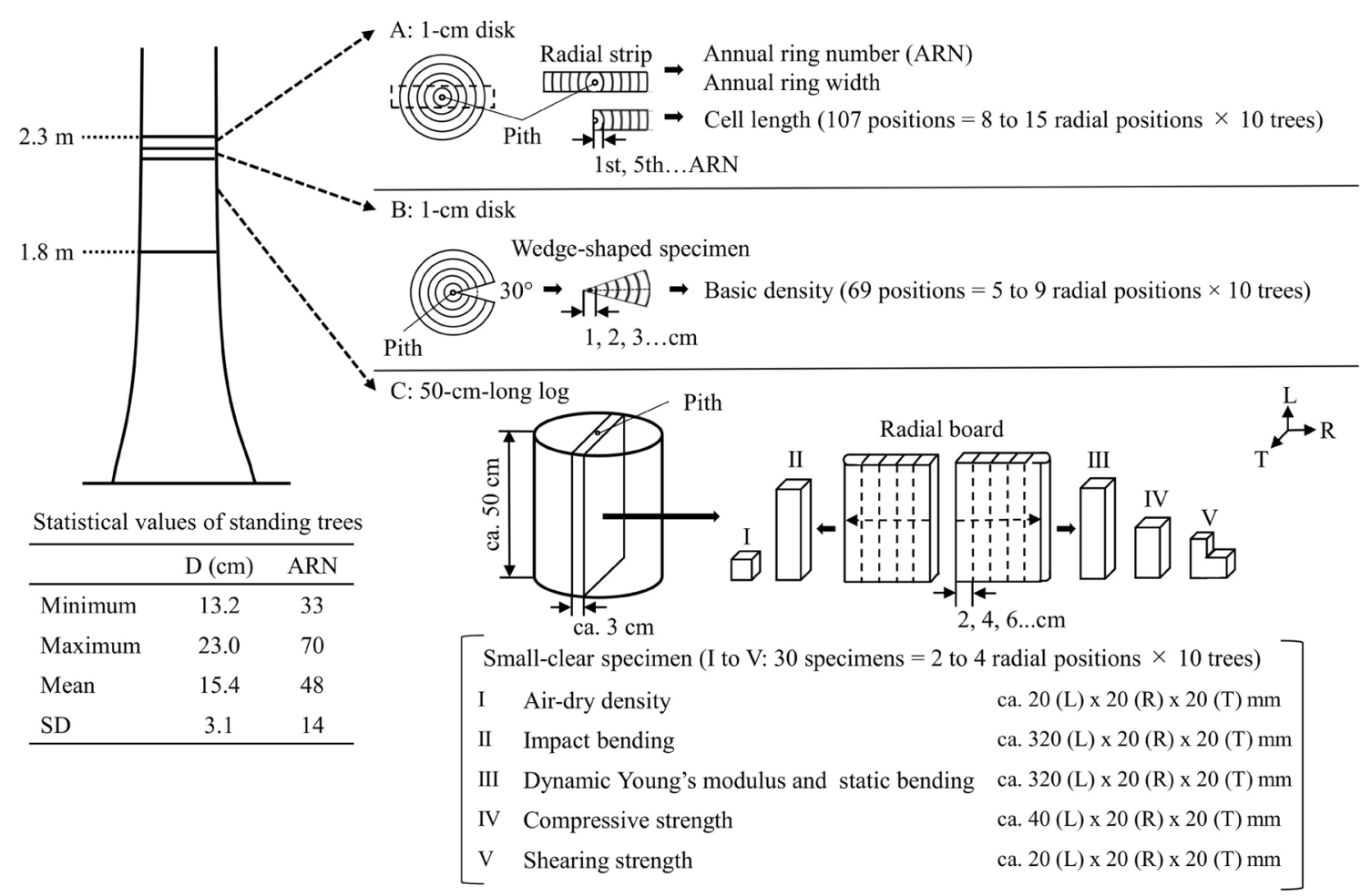

Fig. 1 Illustration of the experimental procedures. Number of trees =10. D, stem diameter at $1.3 \mathrm{~m}$ above the ground 
were obtained for each tree from 1.8 to $2.3 \mathrm{~m}$ above the ground (Fig. 1).

\section{Annual ring width and cell length}

Bark-to-bark radial strips, $10 \mathrm{~mm}$ in thickness, were obtained from 1-cm disks to measure the annual ring number and width (Fig. 1). The transverse sectional images ( $600 \mathrm{dpi})$ of radial strips in one direction from the pith to bark were captured using a scanner (GT-9300UF, Epson, Nagano, Japan). The annual ring width was measured using ImageJ (National Institutes of Health, Bethesda, MD, USA).

To determine the length of the wood fiber and vessel element, pith-to-bark radial strips (10 $\mathrm{mm}$ in thickness) were also obtained from the $1-\mathrm{cm}$ disks (Fig. 1). Small stick specimens were obtained at 5-year intervals from the pith-to-bark radial strips. The stick specimens were collected from a total of 107 radial positions (eight to 15 radial positions $\times 10$ trees). The stick specimens were macerated with Schultze's solution (6 $\mathrm{g}$ of potassium chlorate in $100 \mathrm{~mL}$ of $35 \%$ nitric acid). A total of 50 wood fibers and 30 vessel elements at each radial position were measured using a micro projector (V-12, Nikon, Tokyo, Japan) and a digital caliper (CD-15CP, Mitutoyo, Tokyo, Japan).

\section{Physical and mechanical properties}

In the present study, the following physical and mechanical properties were determined: basic density, air-dry density, dynamic Young's modulus, static bending, impact bending, compressive strength, and shearing strength (Fig. 1).

To determine the basic density, wedge-shaped specimens $\left(30^{\circ}\right.$ at the central angle) were prepared from the disk (Fig. 1). The wedge-shaped specimens were then cut again into smaller specimens at $1-\mathrm{cm}$ intervals from the pith. The basic density was calculated by dividing the oven-dried weight by the green volume measured using the water displacement method.

Physical and mechanical properties, except for basic density and air-dry density, were measured according to Japanese Industrial Standard Z 2101:2009 [21]. Radial boards about $3 \mathrm{~cm}$ in thickness were obtained from approximately 50 -cm-long logs (Fig. 1). The boards were dried in the laboratory at $22{ }^{\circ} \mathrm{C}$ and $65 \%$ relative humidity for 3 months. After air drying, the boards were planed to a thickness of $20 \mathrm{~mm}$ in the tangential direction, and then stick specimens were obtained at $20-\mathrm{mm}$ intervals from the pith. The following specimens were prepared: air-dry density specimens of approximately 20 (L) by 20 (R) by 20 (T) mm; dynamic Young's modulus, static, and impact bending specimens of approximately 320 (L) by 20 (R) by $20(\mathrm{~T}) \mathrm{mm}$; compressive strength specimens of approximately $40(\mathrm{~L})$ by $20(\mathrm{R})$ by $20(\mathrm{~T}) \mathrm{mm}$; and shearing strength specimens (chair shape) of approximately 20 (L) by $20(\mathrm{R})$ by $20(\mathrm{~T}) \mathrm{mm}$. A total of 30 specimens (two to four radial positions $\times 10$ trees) were obtained from 10 sample logs.

To determine the air-dry density, small clear specimens were dried in the laboratory at $22{ }^{\circ} \mathrm{C}$ and $65 \%$ relative humidity for 2 weeks. Air-dried density was calculated by dividing the weight by the volume for the three measured dimensions. Moisture content at testing was also determined by the oven-dry method.

The dynamic Young's modulus of small-clear specimens was measured by the lateral vibrational method [22]. A fast Fourier transform comparator (CF-4500, Ono Sokki, Yokohama, Japan) with a sound level meter (LA4440, Ono Sokki, Yokohama, Japan) and microphone (MI-3110, Ono Sokki, Yokohama, Japan) were used to measure the first natural frequency of lateral vibration due to sound emitted by hitting the radial section of a specimen with a small steel hammer.

The static bending test was conducted using a universal testing machine (MSC-5/500-2, Tokyo Testing Machine, Tokyo, Japan). The load was applied to the radial surface at the center of the span $(280 \mathrm{~mm})$ at a rate of $5 \mathrm{~mm} / \mathrm{min}$. The MOE and MOR were calculated from the load and deflection data. The moisture content of the specimens at testing was $10.7 \pm 0.2 \%$.

The impact bending test was conducted using a Charpy impact testing machine with $98-\mathrm{J}$ capacity at maximum pendulum height $\left(162^{\circ}\right.$; MC-10W, Maekawa Testing Machine MFG, Tokyo, Japan). The load was applied to the radial surface at the center of the specimens. The impact work in joules was obtained by the machine's indicator. The absorbed energy during impact bending was calculated by dividing the impact work by the crosssectional area of the specimen. The moisture content of the specimens at testing was $9.9 \pm 0.3 \%$.

The compressive strength test was conducted using a universal testing machine (RTF-2350, A\&D, Tokyo, Japan) at a load speed of $0.5 \mathrm{~mm} / \mathrm{min}$. The compressive strength parallel to the grain was calculated by dividing the maximum load by the cross-sectional area of the specimen. The moisture content was $10.7 \pm 0.2 \%$ at testing.

The shearing strength test was conducted using a universal testing machine (MSC-5/500-2) with a load rate of $0.5 \mathrm{~mm} / \mathrm{min}$. The shearing strength was determined by dividing the maximum load by the plane area. The moisture content of the specimens was $10.1 \pm 0.2 \%$ at testing.

\section{Statistical analyses}

Statistical analyses were conducted using R software [23]. To evaluate the radial variations, data of the physical and 
mechanical properties determined at 1 - or 2 -cm intervals from the pith were converted to cambial age by the radial variation in the annual ring width. The annual ring number from the pith in a specimen was regarded as the annual ring number from the pith at the middle position of the 1- or 2-cm specimens.

To estimate the distance from the pith in relation to the annual ring number, a nonlinear mixed-effects model was developed using the nlme function in the nlme package [24]. The following model was developed:

$$
y_{i j}=\alpha_{0} /\left\{1+\left(\alpha_{1}+a_{j}\right) \cdot \exp \left(-\alpha_{2} \cdot x_{i j}\right)\right\}+e_{i j}
$$

where $y_{i j}$ is the estimated distance from the pith in relation to the $i$ th annual ring number of the $j$ th individual tree; $x_{i j}$ is the $i$ th annual ring number from the pith of the $j$ th individual tree; $\alpha_{0}, \alpha_{1}$, and $\alpha_{2}$ are fixed-effect parameters; $a_{j}$ is a random effect parameter for the individual tree; $e_{i j}$ is residual.

Linear and nonlinear mixed-effects models with random effects at the tree level were developed to determine radial variation in the wood properties in relation to the annual ring number from the pith using the lmer function in the lme4 packages [25] and the nlme function in the nlme package [24], respectively. The following models were developed:

$$
\begin{aligned}
& \text { Model I }: y_{i j}=\beta_{0} x_{i j}+\beta_{1}+u_{j}+e_{i j} \\
& \text { Model II }: y_{i j}=\beta_{0} \ln \left(x_{i j}\right)+\beta_{1}+u_{j}+e_{i j} \\
& \text { Model III }: y_{i j}=\beta_{0} x_{i j}^{2}+\beta_{1} x_{i j}+\beta_{2}+u_{j}+e_{i j}
\end{aligned}
$$

where $y_{i j}$ is the measured value for the $i$ th annual ring number from the pith of the $j$ th individual tree; $x_{i j}$ is the $i$ th annual ring number from the pith of the $j$ th individual tree; $\alpha_{0}, \alpha_{1}$, and $\alpha_{2}$ are fixed effect parameters; $u_{j}$, is random effect parameter of the $j$ th individual tree; $e_{i j}$ is residual.

Model selection was performed using the Akaike Information Criterion (AIC) [26]. The best model (smallest AIC value) was selected from the developed models.

To evaluate the boundary between the core wood and outer wood, wood fiber length at each annual ring number was estimated using the regression formula based on the best model (selected by AIC value). The boundary was defined as the increase ratio of wood fiber length in the present year to one previous year reached 1.0\% [9, 15]. In addition, each wood property was estimated at the annual ring number from the pith to the 70th annual ring number from the pith in each tree by the regression formula based on the best model. Mean values of each wood property in each tree were calculated for the core wood (from first to boundary annual ring number determined by the annual increment of wood fiber length) and outer wood (from boundary annual ring number to 70th annual ring). A significant difference in estimated wood properties between the core wood and outer wood was detected by conducting a paired $t$ test for the mean values of 10 trees. The relationships among the examined wood properties of the small clear specimens were determined using Pearson's correlation coefficient.

\section{Results and discussion Annual ring width}

The mean value of the annual ring width $(1.37 \mathrm{~mm}$; Table 1) was similar to those of Betula species grown in Mongolia, Japan [8, 9], and Finland [27]. Figure 2 shows the distance from the pith in relation to the annual ring number from the pith. The distance from the pith in relation to the annual ring number was well-adapted to logistic functions based on the random effects of individual trees. Lee et al. [28] reported that the coefficient $\alpha_{0}$ in the logistic formula used in the present study represents an upper limit of growth determined by environmental conditions, and its derivative $\alpha_{0} / 2$ gives the possible maximum growth rate of $y$. In the present study, the coefficient $\alpha_{0}$ was 72.086 , suggesting that the $y$ value showing the maximum growth rate was 36.043 . Thus, the annual ring

Table 1 Statistical values of wood properties for the sampled trees

\begin{tabular}{lcccc}
\hline Property & Minimum & Maximum & Mean & SD \\
\hline Annual ring width $(\mathrm{mm})$ & 0.87 & 1.75 & 1.37 & 0.25 \\
WFL $(\mathrm{mm})$ & 0.93 & 1.21 & 1.03 & 0.09 \\
VEL $(\mathrm{mm})$ & 0.55 & 0.71 & 0.61 & 0.05 \\
$\mathrm{BD}\left(\mathrm{g} / \mathrm{cm}^{3}\right)$ & 0.45 & 0.61 & 0.55 & 0.05 \\
$\mathrm{AD}\left(\mathrm{g} / \mathrm{cm}^{3}\right)$ & 0.58 & 0.75 & 0.64 & 0.05 \\
$\mathrm{DMOE}(\mathrm{GPa})$ & 7.84 & 13.50 & 11.20 & 1.95 \\
$\mathrm{MOE}(\mathrm{GPa})$ & 6.14 & 10.56 & 8.75 & 1.44 \\
$\mathrm{MOR}(\mathrm{MPa})$ & 63.2 & 109.8 & 85.8 & 14.6 \\
$\mathrm{U}\left(\mathrm{kJ} / \mathrm{m}^{2}\right)$ & 49.0 & 92.2 & 72.3 & 16.8 \\
$\mathrm{CS}(\mathrm{MPa})$ & 36.9 & 50.3 & 43.5 & 4.7 \\
$\mathrm{SS}(\mathrm{MPa})$ & 7.7 & 11.8 & 9.4 & 1.3 \\
\hline
\end{tabular}

Number of trees $=10$. SD, standard deviation; WFL, wood fiber length; VEL, vessel element length; $B D$, basic density; $A D$, air-dry density after drying at around $22{ }^{\circ} \mathrm{C}$ and $65 \%$ relative humidity for 2 weeks $(11.3 \pm 0.5 \%$ of moisture content); DMOE, dynamic Young's modulus; MOE, modulus of elasticity; MOR, modulus of rupture; $\mathrm{U}$, absorbed energy in impact bending; $\mathrm{CS}$, compressive strength parallel to grain; $\mathrm{SS}$, shearing strength of small clear specimens. Mean values of moisture content of specimens were $10.7 \pm 0.2 \%, 9.9 \pm 0.3 \%$, $10.7 \pm 0.2 \%$, and $10.1 \pm 0.2 \%$ for static bending, impact bending, compressive strength, and shearing strength specimens, respectively

number from the pith showing the maximum growth rate was 28.8. In addition, the radial growth stabilized around 




Fig. 2 Radial variation in growth rate (distance from the pith) for the sampled trees. Number of trees $=10$. Solid curve indicates the regression curve fitted by the nonlinear mixed-effects model

the 60th annual ring number from the pith (Fig. 2). Thus, the optimum harvesting age for $B$. platyphylla grown in Mongolia is between 30 and 60 years according to the diameter growth rate.

\section{Mean values of wood properties}

Table 1 shows the mean values of the wood properties of $B$. platyphylla naturally grown in Mongolia. Wood fiber length and vessel element length ranged from 0.93 to $1.21 \mathrm{~mm}$ and from 0.55 to $0.71 \mathrm{~mm}$, respectively. Mean values of basic density and air-dry density were 0.55 and $0.64 \mathrm{~g} / \mathrm{cm}^{3}$, respectively. In addition, the mean value of dynamic Young's modulus was $11.20 \mathrm{GPa}$, MOE was $8.75 \mathrm{GPa}$, MOR was $85.8 \mathrm{MPa}$, absorbed energy in impact bending was $72.3 \mathrm{~kJ} / \mathrm{m}^{2}$, compressive strength was $43.5 \mathrm{MPa}$, and shearing strength was $9.4 \mathrm{MPa}$. The mean values for cell length were similar to those obtained by previous researchers for the same species or genus (Table 2) [1,9]. Although MOE and MOR showed similar values with those of the same species [3, 9, 17], these values were relatively low compared to those in the same genus [17, 20, 29-32].

\section{Modeling of radial variations of wood properties}

In the present study, radial variations of wood properties were fitted to three different mixed-effects models: linear, logarithmic, and quadratic formula. Table 3 shows AIC values in developed models for each wood property. For all properties, Model II (the logarithmic formula) showed the smallest AIC values among the three developed models. The regression curves for the fixed effects in the selected logarithmic formula are shown in Fig. 3. All wood properties increased from the pith to the bark and then became constant toward the bark side. The radial variations in the wood properties in the present study were similar to those obtained for the same species or the same genus in other studies $[1,8-10,16,17,20,30]$.

Erdene-Ochir et al. [9] reported that the wood properties of $B$. platyphylla naturally grown in Mongolia differed between the core wood and outer wood; the boundary determined by radial variations in the basic density and compressive strength was around $2 \mathrm{~cm}$ from the pith or the 10th to 20th annual ring from the pith. In $B$. platyphylla naturally grown in Japan, the boundary determined by fiber length was 1.5 to $4.2 \mathrm{~cm}$ or the 10th to 17th annual ring from the pith. In the present study, the boundary between the core wood and outer wood was determined by the annual increment in wood fiber length at each annual ring number estimated by Model II (Table 3). Table 4 shows the boundary annual ring number for each tree. The annual ring number from the pith at the boundary between the core wood and outer wood ranged from the 15th to 17th annual ring number from the pith. The obtained boundary annual ring number in the present study was in accordance with the B. platyphylla trees grown in Mongolia and Japan [8, 9].

To compare the wood properties between the core wood and outer wood, all examined properties were estimated using the best models for evaluating the radial variations of wood properties (Model II; Table 3). Significant differences were found between the core wood and outer wood for all examined wood properties (Table 5). Compared with the core wood, wood with a longer cell length, higher density, and higher strength could be obtained from the outer wood (outside the 20th annual ring from the pith). These differences in wood properties may affect wood utilization of this species; outer wood can be used as high-quality wood for structural products, furniture, and other uses.

Figure 4 shows the relationship between the mean annual ring width until the boundary annual ring number (cambial age) between the core wood and outer wood and annual ring number from the pith at the boundary. No significant negative correlation coefficient was found between annual ring width until the boundary ring number and the annual ring number from the pith at the boundary $(r=-0.17, p<0.645)$, indicating that the radial growth rate at the early growth stage did not affect the xylem maturation age in $B$. platyphylla trees grown in Mongolia.

\section{Relationships among measured wood properties}

Table 6 shows the correlation coefficients among all examined wood properties of the sampled trees. A significant correlation coefficient $(r=0.89, p<0.001)$ was found between the wood fiber length and vessel element length, suggesting that the length of wood fibers and vessel elements is closely linked to each other for this species. A similar tendency was also observed in the studies by [1] and [9].

Previous studies investigating the correlation of radial growth rate with cell length, wood density, and 


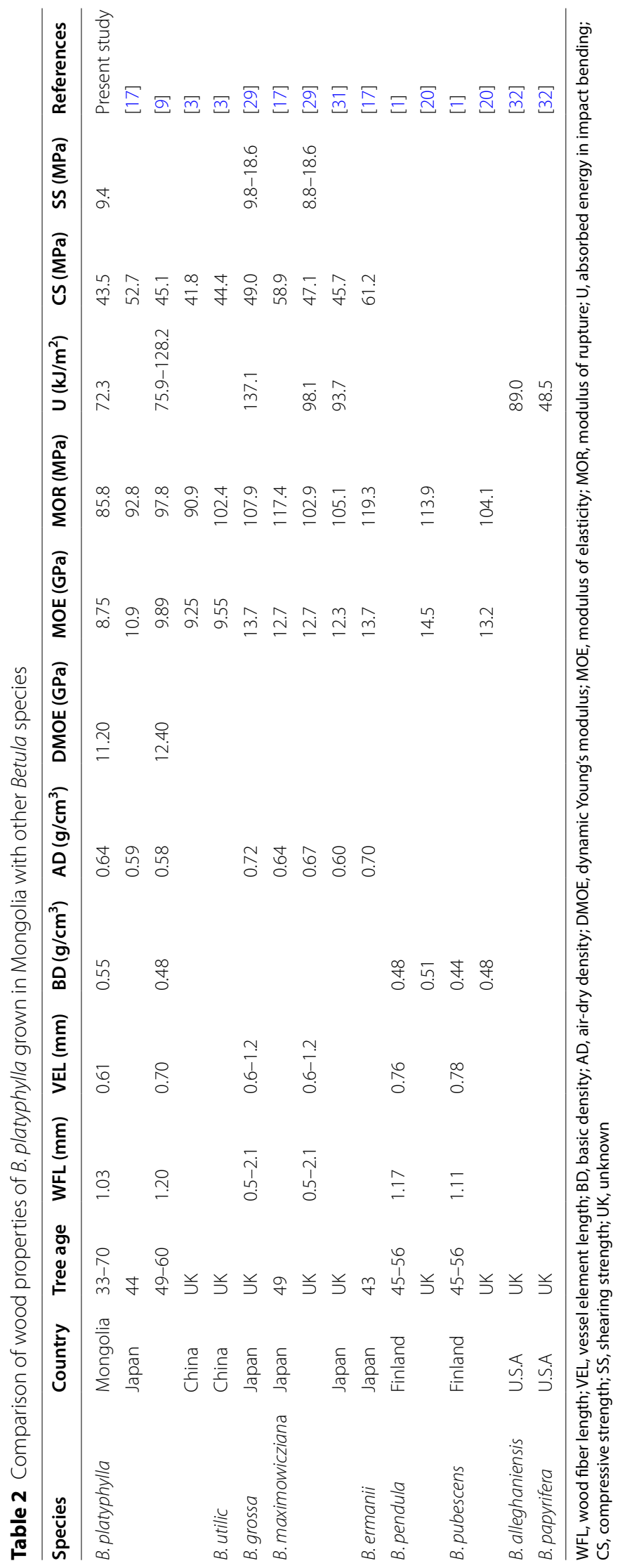


Table 3 Comparison of AIC values in the linear and nonlinear mixed-effects models for radial variations in the wood properties in relation to cambial age

\begin{tabular}{lccc}
\hline Property & Model I & Model II & Model III \\
\hline WFL & -138.98 & $\mathbf{- 2 2 4 . 9 1}$ & -192.38 \\
VEL & -315.07 & $\mathbf{- 3 2 5 . 4 1}$ & -320.24 \\
BD & -209.97 & $\mathbf{- 2 3 9 . 7 5}$ & -209.04 \\
AD & -62.67 & $\mathbf{- 7 1 . 2 5}$ & -45.98 \\
DMOE & 123.38 & $\mathbf{1 1 0 . 5 4}$ & 128.95 \\
MOE & 113.46 & $\mathbf{1 0 3 . 4 3}$ & 123.21 \\
MOR & 258.10 & $\mathbf{2 5 2 . 4 9}$ & 266.34 \\
U & 248.73 & $\mathbf{2 4 2 . 5 7}$ & 253.86 \\
CS & 184.71 & $\mathbf{1 7 5 . 3 5}$ & 193.46 \\
SS & 112.06 & $\mathbf{9 8 . 4 6}$ & 123.28 \\
\hline
\end{tabular}

Number of trees $=10$. AIC, Akaike Information Criterion; WFL, wood fiber length; VEL, vessel element length; $B D$, basic density; $A D$, air-dry density after drying at around $22^{\circ} \mathrm{C}$ and $65 \%$ relative humidity for 2 weeks $(11.3 \pm 0.5 \%$ of moisture content); DMOE, dynamic Young's modulus; MOE, modulus of elasticity; MOR, modulus of rupture; $\mathrm{U}$, absorbed energy in impact bending; $\mathrm{CS}$, compressive strength parallel to grain; $\mathrm{SS}$, shearing strength of small clear specimens. Formulae for the models are listed in Table 2. Bold indicates the smallest AIC among the developed models for each of the examined wood properties

mechanical properties (MOE, MOR, and compressive strength) in B. pendula, B. platyphylla, B. pubescens, and $B$. utilis concluded that radial growth rate had no significant influence on cell length, wood density, or the mechanical properties for Betula species [1, 3, 9]. In addition, there is little correlation between ring width and wood density in diffuse-porous wood [11]. In the present study, stem diameter/annual ring width was not found to be significantly correlated with cell length, basic density, or most mechanical properties. The exceptions were negative correlations found for annual ring width with airdry density, MOR, and compressive strength (Table 6). These results indicated that cell length, basic density, and most of the mechanical properties of $B$. platyphylla are independent from growth characteristics.

It is well-known that wood density is closely related to mechanical properties [3, 10, 11, 19]. As shown in Table 6, basic density or air-dry density was positively correlated with dynamic Young's modulus, MOE, MOR, and compressive strength but not with absorbed energy in impact bending or shearing strength. These results indicate that wood density is a good indicator for predicting the strength properties of $B$. platyphylla wood. Dynamic Young's modulus was found to be positively significantly correlated with MOE, MOR, and compressive strength (Table 6), suggesting that the mechanical properties of B. platyphylla (except for absorbed energy in impact bending and shearing strength) can be predicted by dynamic Young's modulus.
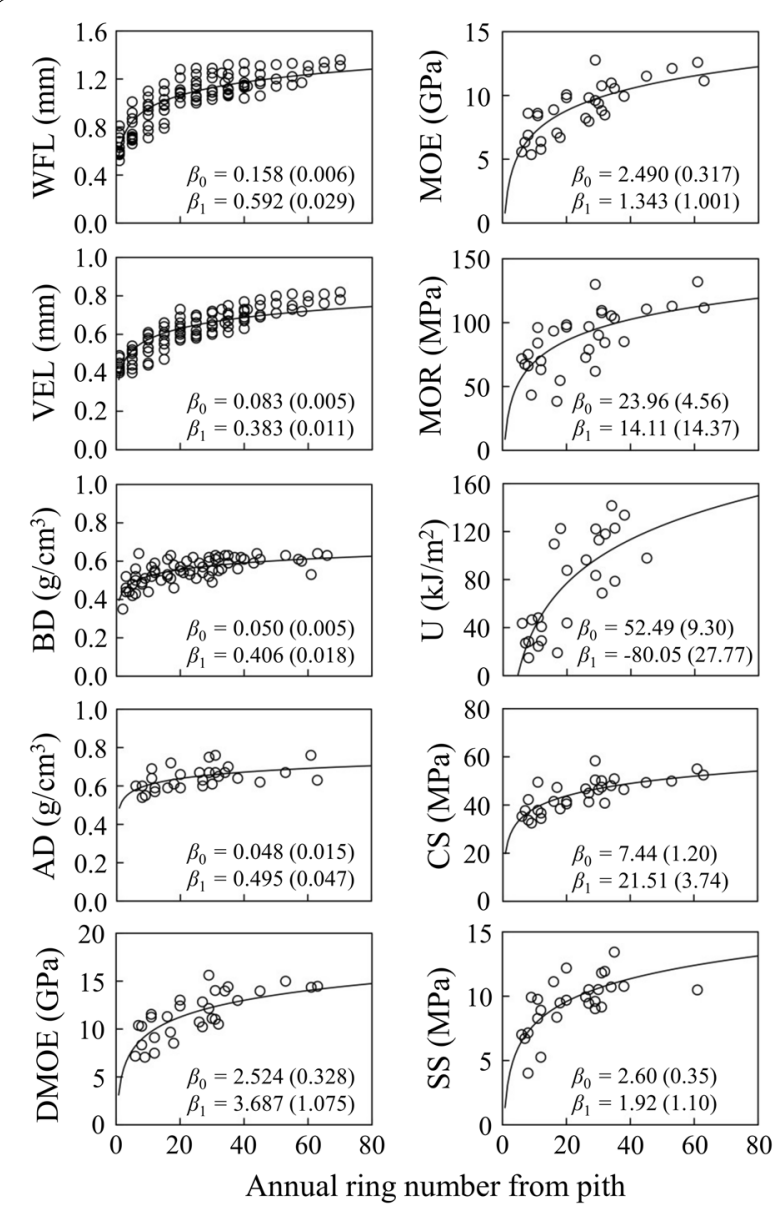

Fig. 3 Radial variations of wood properties in the sampled trees. Number of trees $=10$. WFL, wood fiber length; VEL, vessel element length; $B D$, basic density; $A D$, air-dry density after drying at around $22^{\circ} \mathrm{C}$ and $65 \%$ relative humidity for 2 weeks $(11.3 \pm 0.5 \%$ of moisture content); DMOE, dynamic Young's modulus; MOE, modulus of elasticity; MOR, modulus of rupture; $U$, absorbed energy in impact bending; CS, compressive strength parallel to grain; SS, shearing strength of small-clear specimens. Solid curves indicate the regression curves fitted by fixed-effect parameters in the nonlinear mixed-effects models (Model II in Table 3). Values in parentheses after slope and intercept indicate standard errors

\section{Implications of sustainable forestry and wood utilization in Mongolia}

In the present study, result of radial growth rate indicated that optimum harvesting age in respect to radial growth rate was 30-60 years for B. platyphylla grown in Mongolia (Fig. 2). Even in climatic conditions are severe in Mongolia, B. platyphylla trees can grow well and wood resources of $B$. platyphylla can be sustainably obtained from 30 to 60 year rotation, suggesting that sustainable forestry might be established in Mongolia.

Based on the regression models for radial variations of cell length, physical and mechanical properties (Fig. 3 
Table 4 Annual ring number at the boundary between the core wood and outer wood as determined by the regression formula based on the best model for wood fiber length in each tree

\begin{tabular}{lcl}
\hline Tree number & $\boldsymbol{u}_{\boldsymbol{i}}$ & $\begin{array}{l}\text { Boundary } \\
\text { annual ring } \\
\text { number }\end{array}$ \\
\hline 1 & 0.133 & 15 \\
2 & -0.010 & 16 \\
3 & 0.106 & 15 \\
4 & 0.032 & 15 \\
5 & -0.019 & 16 \\
6 & -0.082 & 17 \\
7 & -0.053 & 17 \\
8 & -0.070 & 17 \\
9 & 0.006 & 16 \\
10 & 0.042 & 16 \\
\hline
\end{tabular}

$u_{i}$, random effect parameter at individual tree level. Wood fiber length at every annual ring was estimated by Model II $\left(y_{i j}=\beta_{0} \ln \left(x_{i j}\right)+\beta_{1}+u_{i}+e_{i j ;} \beta_{0}=0.158\right.$, $\left.\beta_{1}=0.592\right)$ listed in Table 2. Annual ring number at the boundary was regarded as the annual ring number at which the annual increment of wood fiber length became less than $1 \%$

Table 5 Estimations of wood properties of the core wood and outer wood using the best model for comparison between core wood and outer wood

\begin{tabular}{lcccccc}
\hline Property & \multicolumn{2}{l}{ Core wood } & & \multicolumn{2}{c}{ Outer wood } & \multirow{2}{*}{ t value ( $\boldsymbol{p}$ value) } \\
\cline { 2 - 3 } & Mean & SD & & Mean & SD & \\
\hline WFL $(\mathrm{mm})$ & 0.89 & 0.07 & & 1.17 & 0.07 & $-0.281(<0.001)$ \\
VEL $(\mathrm{mm})$ & 0.54 & 0.01 & & 0.69 & 0.01 & $-0.146(<0.001)$ \\
$\mathrm{BD}\left(\mathrm{g} / \mathrm{cm}^{3}\right)$ & 0.50 & 0.03 & & 0.59 & 0.03 & $-0.089(<0.001)$ \\
$\mathrm{AD}\left(\mathrm{g} / \mathrm{cm}^{3}\right)$ & 0.59 & 0.00 & & 0.67 & 0.00 & $-0.085(<0.001)$ \\
$\mathrm{DMOE}(\mathrm{GPa})$ & 8.52 & 1.08 & & 13.02 & 1.09 & $-4.499(<0.001)$ \\
$\mathrm{MOE}(\mathrm{GPa})$ & 5.65 & 1.35 & & 9.70 & 2.51 & $-4.049(<0.001)$ \\
$\mathrm{MOR}(\mathrm{MPa})$ & 60.0 & 6.5 & & 102.8 & 6.8 & $-42.731(<0.001)$ \\
$\mathrm{U}\left(\mathrm{kJ} / \mathrm{m}^{2}\right)$ & 40.5 & 3.5 & & 113.9 & 5.2 & $-73.349(<0.001)$ \\
$\mathrm{CS}(\mathrm{MPa})$ & 35.8 & 0.7 & & 49.0 & 0.7 & $-13.260(<0.001)$ \\
$\mathrm{SS}(\mathrm{MPa})$ & 6.8 & 1.1 & & 11.4 & 1.0 & $-4.550(<0.001)$ \\
\hline
\end{tabular}

Number of trees $=10$. WFL, wood fiber length; VEL, vessel element length; BD, basic density; $A D$, air-dry density after drying at around $22{ }^{\circ} \mathrm{C}$ and $65 \%$ relative humidity for 2 weeks ( $11.3 \pm 0.5 \%$ of moisture content); DMOE, dynamic Young's modulus; $M O E$, modulus of elasticity; MOR, modulus of rupture; $U$, absorbed energy in impact bending; CS, compressive strength parallel to grain; SS, shearing strength of small clear specimens. Wood properties were estimated from the first to 70th annual ring in each tree using the best developed model for the radial pattern (Model II, Tables 2 and 5). The means and standard deviations (SDs) of the core wood and outer wood were calculated from the first ring to boundary age (listed in Table 6 ) and from the boundary age to 70th annual ring, respectively. Significant differences between the core and outer wood were detected using a paired $t$ test

and Table 3), the wood of this species can be divided into two parts, core wood and outer wood, at around 15th to 17 th annual ring number from the pith (Tables 4 and 5 ). The core wood was characterized by unstable values

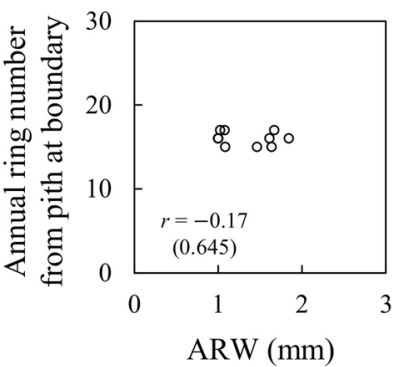

Fig. 4 Relationship between mean annual ring width until boundary annual ring number between core wood and outer wood, and annual ring number from the pith of the boundary. Number of trees $=10$. Mean annual ring width (ARW) until annual ring number of the boundary was calculated by averaging the annual ring width from the first to boundary ring number in each tree listed in Table 4

of anatomical characteristics as well as cell length, and physical and mechanical properties, whereas outer wood has stable values. Therefore, it is suggested that when the wood of B. platyphylla is utilized, the presence of core wood and outer wood should be considered. The core wood of this species should be used for fuel wood, raw materials for charcoal, pulp and paper, and wood-based materials. On the other hand, the outer wood with stable properties can be used for furniture, interior wood, and structural lumber.

\section{Conclusions}

In the present study, wood properties were investigated for 10 naturally regenerated $B$. platyphylla trees grown in Mandal, Selenge, Mongolia to effectively utilize the wood resources. The mean values of wood properties of B. platyphylla grown in Mongolia were similar with those in B. platyphylla trees grown in Mongolia and Japan and B. pendula and B. pubescens grown in Finland. A nonlinear mixed-effects model (logarithmic formula) was welladapted to the radial variations in the wood properties of B. platyphylla; all examined properties increased from the pith toward the bark side (increase in the number of annual rings) and then stabilized toward the bark. The wood properties significantly differed between the core and outer wood. In addition, the radial growth rate at the early growth stage did not affect the xylem maturation age in B. platyphylla trees grown in Mongolia. Based on the results of the correlation analysis, the cell length and most of the physical and mechanical properties of $B$. platyphylla were independent from growth characteristics. Significant positive correlations were obtained for basic density, air-dry density, and dynamic Young's modulus with mechanical properties (i.e., MOE, MOR, and compressive strength). When the wood of B. platyphylla is utilized in industrial materials, the differences between 
Table 6 Correlation coefficients and significant correlations $p$ values among measured wood properties of the sampled trees

\begin{tabular}{ccccccccccccc}
\hline Property & D & ARW & WFL & VEL & BD & AD & DMOE & MOE & MOR & U & CS & SS \\
\hline D & & 0.701 & 0.765 & 0.858 & 0.459 & 0.471 & 0.214 & 0.230 & 0.946 & 0.348 & 0.066 & 0.670 \\
ARW & -0.14 & & 0.235 & 0.153 & 0.090 & 0.031 & 0.213 & 0.198 & 0.035 & 0.854 & 0.035 & 0.740 \\
WFL & -0.11 & -0.41 & & 0.000 & 0.362 & 0.244 & 0.092 & 0.054 & 0.028 & 0.472 & 0.122 & 0.042 \\
VEL & 0.07 & -0.49 & $\mathbf{0 . 8 9}$ & & 0.167 & 0.062 & 0.010 & 0.005 & 0.009 & 0.303 & 0.013 & 0.144 \\
BD & 0.27 & -0.56 & 0.32 & 0.47 & & 0.209 & 0.031 & 0.038 & 0.030 & 0.899 & 0.027 & 0.581 \\
AD & 0.26 & $-\mathbf{0 . 6 8}$ & 0.41 & 0.61 & 0.43 & & 0.046 & 0.064 & 0.089 & 0.407 & 0.008 & 0.672 \\
DMOE & 0.43 & -0.43 & 0.56 & $\mathbf{0 . 7 6}$ & $\mathbf{0 . 6 8}$ & $\mathbf{0 . 6 4}$ & & 0.000 & 0.003 & 0.251 & 0.002 & 0.991 \\
MOE & 0.42 & -0.44 & 0.62 & $\mathbf{0 . 8 0}$ & $\mathbf{0 . 6 6}$ & 0.61 & $\mathbf{0 . 9 9}$ & & 0.002 & 0.237 & 0.002 & 0.887 \\
MOR & 0.02 & $-\mathbf{0 . 6 7}$ & $\mathbf{0 . 6 9}$ & $\mathbf{0 . 7 7}$ & $\mathbf{0 . 6 8}$ & 0.57 & $\mathbf{0 . 8 3}$ & $\mathbf{0 . 8 5}$ & & 0.100 & 0.024 & 0.977 \\
U & 0.33 & -0.07 & -0.26 & -0.36 & 0.05 & -0.30 & -0.40 & -0.41 & -0.55 & & 0.766 & 0.621 \\
CS & 0.60 & $-\mathbf{0 . 6 7}$ & 0.52 & $\mathbf{0 . 7 5}$ & $\mathbf{0 . 6 9}$ & $\mathbf{0 . 7 8}$ & $\mathbf{0 . 8 5}$ & $\mathbf{0 . 8 5}$ & $\mathbf{0 . 7 0}$ & -0.11 & & 0.917 \\
SS & 0.15 & -0.12 & $-\mathbf{0 . 6 5}$ & -0.50 & 0.20 & -0.15 & 0.00 & -0.05 & -0.01 & -0.18 & -0.04 & \\
\hline
\end{tabular}

Number of trees $=10 . \mathrm{D}$, stem diameter at $1.3 \mathrm{~m}$ above the ground; ARW, annual ring width; WFL, wood fiber length; VEL, vessel element length; BD, basic density; $A D$, air-dry density after drying at around $22{ }^{\circ} \mathrm{C}$ and $65 \%$ relative humidity for 2 weeks ( $11.3 \pm 0.5 \%$ of moisture content); DMOE, dynamic Young's modulus; MOE, modulus of elasticity; MOR, modulus of rupture; $\mathrm{U}$, absorbed energy in impact bending; $\mathrm{CS}$, compressive strength parallel to grain; SS, shearing strength of small clear specimens. Values in left and right sides of diagonal show correlation coefficients and significant correlations $p$ values. Correlation coefficients with bold style indicate correlation coefficients with $p$ value less than 0.05

the core wood and outer wood should be considered. In addition, wood density and dynamic Young's modulus are suitable for predicting the higher strength properties of wood in this species.

\section{Abbreviations}

MOE: Modulus of elasticity; MOR: Modulus of rupture; AIC: Akaike information criterion.

\section{Acknowledgements}

The authors would like to thank Mr. Batchuluun Demiddavga and Altanbagana Jinguuz for their assistance with the field sampling

\section{Authors' contributions}

TE contributed to experiments, data analysis, and writing the manuscript. FI designed this study and contributed to experiments, data analysis, and writing the manuscript. IN contributed to experiments and data analysis. BT, BB and GC contributed to experiments. JO and SY contributed to discussion on the obtained results. All authors read and approved the final manuscript.

\section{Funding}

Part of this research was financially supported by the Higher Engineering Education Development Project, implemented by the Ministry of Education, Culture, Science, and Sports, Mongolia.

\section{Availability of data and materials}

Not applicable.

\section{Declarations}

Ethics approval and consent to participate

The wood samples used in the present study were collected with the observance of Mongolian laws.

\section{Consent for publication}

Not applicable.

\section{Competing interests}

The authors declare that they have no competing interests.

\section{Author details}

${ }^{1}$ School of Agriculture, Utsunomiya University, Utsunomiya, Tochigi 321-8505, Japan. ${ }^{2}$ United Graduate School of Agricultural Science, Tokyo University of Agriculture and Technology, Fuchu, Tokyo 183-8509, Japan. ${ }^{3}$ Training and Research Institute of Forestry and Wood Industry, Mongolian University of Science and Technology, Ulaanbaatar 15172, Mongolia. ${ }^{4}$ School of Industrial Technology, Mongolian University of Science and Technology, Ulaanbaatar 14191, Mongolia.

Received: 24 July 2021 Accepted: 12 October 2021

Published online: 29 October 2021

\section{References}

1. Bhat KM (1980) Variation in structure and selected properties of Finnish birch wood I: interrelationships of some structural features, basic density and shrinkage. Silva Fenn 14:384-396. https://doi.org/10.14214/sf.a15032

2. Zhang SY (1995) Effect of growth rate on wood specific gravity and selected mechanical properties in individual species from distinct wood categories. Wood Sci Technol 29:451-465. https://doi.org/10.1007/BF001 94204

3. Zhang SY (1997) Wood specific gravity-mechanical property relationship at species level. Wood Sci Technol 31:181-191. https://doi.org/10.1007/ BF00705884

4. efloras (2008) Missouri botanical garden, St. Louis, MO \& Harvard University Herbaria, Cambridge, MA, http://www.efloras.org. Accessed 11 June 2020

5. Badarch S, Namsrai D (2009) Study on mechanical properties of birch wood. Acad Bull Train Res Inst For Wood Ind, Mongolian Univ Sci Technol 105:168-181 (In Mongolian)

6. Dubois H, Verkasalo E, Claessens H (2020) Potential of birch (Betula pendula Roth and B. pubescens Ehrh.) for forestry and forest-based industry sector within the changing climatic and socio-economic context of western Europe. Forests 11:336. https://doi.org/10.3390/f11030336

7. Viherä-Aarnio A, Velling P (2017) Growth, wood density and bark thickness of silver birch originating from the Baltic countries and Finland in two Finnish provenance trials. Silva Fenn 51:7731. https://doi.org/10. 14214/sf.7731

8. Erdene-Ochir T, Ishiguri F, Nezu I, Tumenjargal B, Baasan B, Chultem G, Ohshima J, Yokota S (2020) Utilization potential of naturally regenerated Mongolian Betula platyphylla wood based on growth characteristics and wood properties. Silva Fenn 54:10284. https://doi.org/10.14214/sf.10284 
9. Erdene-Ochir T, Ishiguri F, Nezu I, Tumenjargal B, Sarkhad M, Ohshima J, Yokota S (2021) Within-tree and radial variations of wood properties in naturally regenerated trees of Betula platyphylla grown in Nikko, Japan. Int Wood Prod J 12:95-106. https://doi.org/10.1080/20426445.2020. 1861733

10. Panshin AJ, de Zeeuw C (1980) Textbook of wood technology: structure, identification, properties, and uses of the commercial woods of the United States and Canada. McGraw-Hill, New York

11. Zobel BJ, van Buijtenen JP (1989) Wood variation: its causes and control. Springer, Berlin

12. Lei H, Milota MR, Gartner BL (1996) Between- and within-tree variation in the anatomy and specific gravity of wood in Oregon white oak (Quercus garryana Dougl.). IAWA J 17:445-461. https://doi.org/10.1163/2294193290000642

13. Bao FC, Jiang ZH, Jiang XM, Lu XX, Luo XQ, Zhang SY (2001) Differences in wood properties between juvenile wood and mature wood in 10 species grown in China. Wood Sci Technol 35:63-375. https://doi.org/10.1007/ s002260100099

14. Ishiguri F, Eizawa J, Saito Y, lizuka K, Yokota S, Priadi D, Sumiasri N, Yoshizawa N (2007) Variation in the wood properties of Paraserianthes falcataria planted in Indonesia. IAWA J 28:339-348. https://doi.org/10. 1163/22941932-90001645

15. Honjo K, Furukawa I, Sahri MH (2005) Radial variation of fiber length increment in Acacia mangium. IAWA J 26:339-352. https://doi.org/10.1163/ 22941932-90000119

16. Fukazawa K (1984) Juvenile wood of hardwoods judged by density variation. IAWA Bull 5:65-73. https://doi.org/10.1163/22941932-90000861

17. Ohsaki H, Murakami S, Akitsu H (2019) The timber properties of birch grown in a plantation in Atsuma, Hokkaido. Mokuzai Gakkaishi 65:189194 (In Japanese with English summary)

18. Dobrowolska E, Wroniszewska P, Jankowska A (2020) Density distribution in wood of European birch (Betula pendula Roth.). Forests 11:445. https:// doi.org/10.3390/f11040445

19. Kollmann FFP, Côté WA Jr (1984) Principles of wood science and technology, I solid wood. Springer, Berlin

20. Heräjärvi H (2004) Static bending properties of Finnish birch wood. Wood Sci Technol 37:523-530. https://doi.org/10.1007/s00226-003-0209-1
21. JIS (2009) Methods of tests for woods. Japanese Standard Association, Tokyo (In Japanese)

22. Bucur V (2006) Acoustics of wood, 2nd edn. Springer, Berlin

23. R Core Team (2020) A language and environment for statistical computing. R Foundation for Statistical Computing, Vienna, Austria. https:// www.R-project.org/. Accessed 22 June 2020

24. Pinheiro JC, Bates DM (2000) Mixed-effects models in S and S-PLUS Springer, New York

25. Bates D, Mächler M, Bolker BM, Walker SC (2015) Fitting linear mixedeffects models using Ime4. J Stat Softw 67:1-48. https://doi.org/10. 18637/jss.v067.i01

26. Akaike H (1998) Selected papers of Hirotugu Akaike: Springer series in statistics. In: Parzen E, Tanabe K, Kitagawa G (eds) Springer, New York

27. Luostarinen K, Huotari N, Tillman-Sutela E (2009) Effect of regeneration method on growth, wood density and fiber properties of Downy birch (Betula pubescens Ehrh.). Silva Fenn 43:329-338. https://doi.org/10.14214/ sf.191

28. Lee HS, Itoh A, Kanzaki M, Yamakura T (1997) Height growth of engkabang jantong, Shorea macrophylla (De Vr.) Ashton, in a plantation forest in Sarawak. Tropics 7:67-80. https://doi.org/10.3759/tropics.7.67

29. Wood Technological Association of Japan (1984) Wood of Japan (Nihon no Mokuzai). Japan Wood Technological Association, Tokyo (In Japanese)

30. Furukawa I, Sekoguchi M, Matsuda M, Sakuno T, Kishimoto J (1983) Wood quality of small hardwoods (II) horizontal variations in the length of fibers and vessel elements in seventy-one species of small hardwoods. Hardwood Res 2:103-134 (In Japanese with English Summary)

31. Wood Technology and Wood Utilization Division (1982) Properties of the important Japanese woods, table of the properties of woods. Bull For For Prod Res Inst 319:85-126 (In Japanese with English Summary)

32. Bodig J, Jayne BA (1982) Dynamic behavior. In: Mechanics of wood and wood composites: application of impact to composites. Van Nostrand Reinhold, New York

\section{Publisher's Note}

Springer Nature remains neutral with regard to jurisdictional claims in published maps and institutional affiliations.

\section{Submit your manuscript to a SpringerOpen ${ }^{\circ}$ journal and benefit from:}

- Convenient online submission

- Rigorous peer review

- Open access: articles freely available online

- High visibility within the field

- Retaining the copyright to your article

Submit your next manuscript at springeropen.com 